\title{
Alginate Oligosaccharides Alleviate the Damage of Rice Leaves Caused by Acid Rain and High Temperature
}

\author{
Xu-Jian Yang ${ }^{1,2}$, Yaqi Chen ${ }^{1}$, Zichang $\mathrm{Hu}^{1}$, Shuo Ma ${ }^{1,2}$, Jiaen Zhang ${ }^{1,2, *}$ and Hong Shen ${ }^{1,2, *}$ \\ 1 College of Natural Resources and Environment, South China Agricultural University, \\ Guangzhou 510642, China; yangshenlin@stu.scau.edu.cn (X.-J.Y.); guanc261@gamail.com (Y.C.); \\ hzc.scau@foxmail.com (Z.H.); mashuo@stu.scau.edu.cn (S.M.) \\ 2 Guangdong Provincial Key Laboratory of Eco-Circular Agriculture, Guangzhou 510642, China \\ * Correspondence: jeanzh@scau.edu.cn (J.Z.); hshen@scau.edu.cn (H.S.)
}

check for updates

Citation: Yang, X.-J.; Chen, Y.; Hu, Z.; Ma, S.; Zhang, J.; Shen, H. Alginate Oligosaccharides Alleviate the Damage of Rice Leaves Caused by Acid Rain and High Temperature. Agronomy 2021, 11, 500. https://doi.org/10.3390/ agronomy11030500

Academic Editor: Salvatore Camposeo

Received: 5 February 2021

Accepted: 3 March 2021

Published: 7 March 2021

Publisher's Note: MDPI stays neutral with regard to jurisdictional claims in published maps and institutional affiliations.

Copyright: (c) 2021 by the authors. Licensee MDPI, Basel, Switzerland. This article is an open access article distributed under the terms and conditions of the Creative Commons Attribution (CC BY) license (https:// creativecommons.org/licenses/by/ $4.0 /)$.

\begin{abstract}
Alginate oligosaccharides (AOS) are known for functions in regulating plant growth and stress resistance. This study investigated the damage on rice leaves caused by acid rain (AR) and high temperature (HT) simultaneously, as well as the alleviating effect of AOS on these stresses. The results show that plant biomass and antioxidant enzyme activities (AEAs) after AR treatment reduced more severely under HT conditions than normal-temperature conditions. Both AR and HT triggered the accumulation of reactive oxygen species (ROS) in rice leaves. The suppressing effects of AR and HT were individual in most cases, except for AEAs. Microscopic analysis showed that pH 2 AR and HT injured leaf epidermis, particularly the bulliform cells, the veins and interveinal regions. Spraying AOS resulted in a slight elevation of biomass, a significant increase in AEAs and a remarkable decline in ROS concentrations under HT conditions with AR. Besides, the chlorophyll a contents of a leaf after $\mathrm{pH} 2$ AR plus AOS treatment under HT conditions remained $66.1 \%$ of that after $\mathrm{pH} 7$ treatment under normal-temperature conditions. Moreover, AOS protected the integrity of leaf tissue even after $\mathrm{pH} 3$ treatment. Taken together, the above results suggest that AR and HT inhibited AEAs, led to the accumulation of ROS and damaged rice leaf. However, foliar applying AOS enhanced AEAs, scavenged ROS, and thus alleviated the stress induced by HT and AR.
\end{abstract}

Keywords: rice (Oryza sativa); leaf; simulated acid rain; alginate oligosaccharides; high temperature

\section{Introduction}

The deleterious effects for crop production often originate from several ambient stresses occurring simultaneously [1]. Acidic deposition resulting from $\mathrm{SO}_{2}$ and $\mathrm{NO}_{\mathrm{x}}$ emitted to the atmosphere [2] is one of the essential environmental problems [3,4]. Even though mild acid rain ( $\mathrm{pH} 4.5 \sim 5.5$ ) was reported to benefit seedling germination and shoot growth for certain plants [2], severe acid rain directly and indirectly influences the growth of crops by interfering with a considerable number of biochemical and physiological processes, altering several antioxidant enzyme-mediated reactions, accelerating lipid peroxidation, inhibiting photosynthesis and worsening the rhizosphere condition for nutrient uptake, which leads to nutrient disorder and morphological changes of plants [2,3,5-7]. For instance, cape found that $\mathrm{pH} 3.5$ acid rain can lead to several subtle structural changes in broadleaved tree leaves [8], and Ramlall et al. reported that $\mathrm{pH} 3.0$ acid rain results in chlorotic and necrotic spots in leaf blades of forest natal mahogany (Trichilia dregeana Sond.), accompanying a reduction in leaf chlorophyll concentration and root biomass [9]. Besides, Ren et al. indicated that acid rain at pH 2.5 increases the accumulation of malondialdehyde, superoxide anions and hydrogen peroxide, and promotes membrane permeability in rice (Oryza sativa L.) leave cells [10]. Even though mild acid rain may increase $\mathrm{H}^{+}$ -ATPase activity to pump excessive intracellular $\mathrm{H}^{+}$to intercellular space as a tolerant mechanism [2,11], $5 \mathrm{~d}$ intermittent $\mathrm{pH} 2.5$ acid rain treatment inhibits $\mathrm{H}^{+}$-ATPase activity 
in the plasma membrane of rice seedlings and damages the integrity of the plasma membrane [12]. Accompanying structural damages in the plasma membrane and chlorophyll, $\mathrm{CO}_{2}$ accumulates in intercellular space due to narrower stomata after exposure to acid rain whose $\mathrm{pH}$ was lower than $\mathrm{pH} 3$, and finally the rate of photosynthesis is lowered [13]. Moreover, since the composition of acid rain in southern China has evolved from single $\mathrm{SO}_{4}{ }^{2-}$ type to $\mathrm{SO}_{4}{ }^{2-}-\mathrm{NO}_{3}{ }^{-}$mixed type, the adverse effects become stronger with a longer residual time [14]. However, the growth inhibition of soybean caused by $\mathrm{pH} 4.5$ simulated acid rain can be reversed by sufficient Ca nutrition supply [15]. So, the damaging effects induced by acid rain depend on $\mathrm{pH}$ value and nutrient condition.

Apart from acid rain, seasonal extreme high temperature is another abiotic stress factor resulting in damage to membrane integrity $[16,17]$ and has been an obstacle for crop production in southern China since the 1990s [18]. It has been reported that high temperature inhibits seed germination [19], spikelet fertility and development [20,21]. It also induces reactive oxygen species (ROS) and malondialdehyde accumulation [22,23], and interferes in photosynthesis [24]. However, Yang et al. gave the opposite opinion that a high temperature of $38^{\circ} \mathrm{C}$ enhances photosynthesis if a certain Rubisco isoform activates and the transpiration cooling mechanism works [25]. Therefore, Wang et al. suggested that the physiological effects of high temperature for rice may be diverse during different stages of its life cycle [21].

Brown seaweeds contain abundant bioactive compounds [26], including a series of oligosaccharides extracted from algae, called alginate oligosaccharides (AOS) [27]. Since these compounds are extracted from biorenewable resources [28], AOS are regarded as novel environment-friendly agricultural regulators with great utilization potential [29]. It has been widely reported that AOS promote root growth and development $[30,31]$ as well as nutrient uptake [32,33] of several plants. Besides, as a kind of signal molecule [34], AOS also participate in the drought tolerance of wheat via the abscisic acid-dependent signal pathway [35] and the pathogen resistance of the arabidopsis (Arabidosis thaliana (L.) Heynh) via the salicylic acid-mediated signaling pathway [36]. Moreover, AOS can recover declined biomass and chlorophyll contents of plants caused by saline stress [37,38]. In addition, Tang et al. summarized the contributions of AOS on enhancing the antioxidant enzyme system for saline stress tolerance as: (1) a protective agent for osmotic stress and (2) an analog of auxin [39]. Besides, carrageenan oligosaccharides from red algae also show the significant embryogenic induction effect of broccoli (Brassica oleracea var. italica Plenck) in microspore cultivation [40].

Acid rain and high temperature usually occurred simultaneously in the summer of South China. Although many previous studies have reported the individual effects of acid rain and high temperature on plants, it remains unclear whether there are compound effects, i.e., interaction between these two factors on rice growth. Understanding the underlying damage mechanism of stresses to plants and the response of plants is essential for rescuing losses caused by these stresses [11]. In this study, the compound effects of acid rain and high temperature on the growth of rice seedlings were investigated under greenhouse conditions. The alleviating effect of AOS on acid rain-high temperature compound stress on rice was also investigated. Since the leaf is the major organ suffering stresses of acid rain and high temperature, and AOS with low molecular mass $(<100 \mathrm{kDa})$ can penetrate through stomata [41], AOS was applied by foliar spraying in this study. The findings of this study may be beneficial for alleviating damages due to these two stresses, which often occur simultaneously in southern China.

\section{Materials and Methods}

\subsection{Plant Preparation}

Cultivar 'Tianyou 998', a high-yield rice (Oryza sativa L) cultivar widely planted in southern China, was selected as experimental material in this study. After sterilization and 3 -time deionized water rinsing, the seeds were germinated at $28 \pm 3^{\circ} \mathrm{C}$ for 3 to $5 \mathrm{~d}$. After germination, rice seedlings were transplanted into nutrient solution for $21 \mathrm{~d}$. The nutrient 
solution was prepared according to the formula of Zhu et al. [42]. Then, seedlings were transplanted into soil for further pot experiments. Those experiments were performed after $14 \mathrm{~d}$ of recovery from transplanting, i.e., the seedlings were around $40 \mathrm{~d}$ old before treatments started.

\subsection{Experimental Design}

The seedlings were divided into two groups. One group of seedlings grew in a greenhouse whose highest temperature was at $27 \pm 1{ }^{\circ} \mathrm{C}$ in the daytime, which was assigned as normal-temperature treatment. The other group grew in a greenhouse whose highest temperature was at $32 \pm 1{ }^{\circ} \mathrm{C}$ in the daytime, which was assigned as high-temperature treatment. The lowest temperature of both greenhouses was $20 \pm 1{ }^{\circ} \mathrm{C}$ at night. The length of daytime during the experiment was 13 h, from 5:30 a.m. to 6:30 p.m., while the length of night was $11 \mathrm{~h}$, from 6:30 p.m. to 5:30 a.m.

Five acid rain treatments were set in this study in each temperature treatment group: $\mathrm{pH}$ 2, $\mathrm{pH} 3, \mathrm{pH} 4, \mathrm{pH} 5$ and $\mathrm{pH} 7$ (the control), which covered the $\mathrm{pH}$ range from neutral to extreme cases of acid rain in southern China (the common range of acid rain in this region is 3.5-4.8) $[2,14,43]$, The stock solution of acid rain consisted of sulfuric acid and nitric acid with the molar ratio of 4:1, which was based on the composition of acid rain in Guangzhou [44], and its $\mathrm{pH}$ value was 1.0. Then, the stock solution was diluted to $\mathrm{pH}$ 2.0, 3.0, 4.0 and 5.0, respectively, with deionized water according to theoretical calculation, and then was adjusted with the aforementioned stock solution and $\mathrm{NaOH}$ (if necessary) [2,14,45]. The control treatment ( $\mathrm{pH} 7.0$ ) was deionized water [11]. The rain solution was preheated to the target temperature $\left(32{ }^{\circ} \mathrm{C}\right.$ for high-temperature treatment and $27^{\circ} \mathrm{C}$ for normal-temperature treatment) before $\mathrm{pH}$ adjustment. The experiments were arranged in a complete randomized design. Three replicates were set for each treatment, and two rice plants were in a pot as a replicate. One hundred milliliters of acid rain (including $\mathrm{pH} 7$ deionized water) were sprayed on the rice leaves at 9:00 a.m. every day. The acid drops were sprayed uniformly on all leaves of the whole plant and little rain dropped to the soil. After $7 \mathrm{~d}$ of treatment, intact rice plants were harvested for subsequent analysis, inducing biomass, chlorophyll contents, ROS concentrations and antioxidant enzyme activities, etc., as well as microscopic observation.

In the assay to assess the alleviation effect of AOS, rice plants grew in normal- and high-temperature conditions as described above. The AOS solution in this study was extracted from kelp (Laminaria japonica Aresch.) by enzyme-mediated hydrolysis in the authors' laboratory. It was composed mainly of alginate oligosaccharides, and the $\mathrm{pH}$ of the $37.5 \mathrm{mg} / \mathrm{L}$ AOS solution was 7.0 at $30^{\circ} \mathrm{C}$. Seven-day foliar fertilization was performed and $100 \mathrm{~mL}$ of $37.5 \mathrm{mg} / \mathrm{L}$ AOS was sprayed at 9:00 p.m. every day, which was performed $12 \mathrm{~h}$ before acid rain spraying. The reason for applying AOS at 9:00 p.m. was providing a sufficient exposure interval. During the interval, acid rain solution and AOS solution could not be mixed on the surface of rice leaves. The replicate settings and the acid rain exposure operation were identical to the acid rain exposure experiment described in the above paragraph in this article. After $7 \mathrm{~d}$ of spraying, the whole rice plants were harvested for subsequent assays inducing biomass, chlorophyll contents, ROS concentrations and antioxidant enzyme activities, etc., as well as microscopic observation.

\subsection{Analysis of Biomass in Rice Leaves}

After treatment, harvested rice seedlings were inactivated at $105^{\circ} \mathrm{C}$ for $2 \mathrm{~h}$ and then dried at $65^{\circ} \mathrm{C}$ for $3 \mathrm{~d}$ in a drying chamber. The dry mass (biomass) of rice was weighed on a balance.

\subsection{Measurements of Hydrogen Peroxide $\left(\mathrm{H}_{2} \mathrm{O}_{2}\right)$ and Superoxide Anion $\left(\mathrm{O}_{2}{ }^{-}\right)$in Rice Leaves}

Harvested rice leaves were stored at $4{ }^{\circ} \mathrm{C} . \mathrm{H}_{2} \mathrm{O}_{2}$ accumulation in rice leaves was determined by the titanium sulfate method [46]. Briefly, $0.2 \mathrm{~g}$ of fresh leaves was collected and homogenized with $5 \mathrm{~mL}$ of $50 \mathrm{mmol} / \mathrm{L} \mathrm{pH} 6.8$ phosphate buffer solution (PBS). After centrifugation at $16,000 \times \mathrm{g}$ for $20 \mathrm{~min}$ at $4{ }^{\circ} \mathrm{C}$, the supernatant was collected as extract 
solution. Three milliliters of extract solution was mixed with $1 \mathrm{ml} 1 \mathrm{~g} / \mathrm{L}$ titanium sulfate and the mixture was centrifuged at $16,000 \times g$ for $20 \mathrm{~min}$ at $4{ }^{\circ} \mathrm{C}$. Then, the optical density at $410 \mathrm{~nm}\left(\mathrm{OD}_{410}\right)$ of the supernatant was measured. The concentration of $\mathrm{H}_{2} \mathrm{O}_{2}$ in solution was calculated based on the standard curve and presented in the form of $\mu \mathrm{moL} / \mathrm{g}$ fresh mass (FM).

The measurement of $\mathrm{O}_{2}{ }^{-}$was according to the method of Shah et al. [47]. Briefly, $0.3 \mathrm{~g}$ of fresh rice leaves was homogenized with $5 \mathrm{ml}$ of $100 \mathrm{mmol} / \mathrm{L} \mathrm{pH} 7.2$ PBS containing $1 \mathrm{mmol} / \mathrm{L}$ sodium diethyl dithiocarbamate (superoxide dismutase inhibitor). After centrifugation at $15,000 \times g$ for $30 \mathrm{~min}$ at $4{ }^{\circ} \mathrm{C}$, the supernatant was collected. The $3 \mathrm{~mL}$ reaction mixture for $\mathrm{O}_{2}{ }^{-}$content determination consisted of $1 \mathrm{ml}$ of supernatant, $100 \mathrm{mmol} / \mathrm{L}$ (final concentration, similarly hereafter) PBS, $1 \mathrm{mmoL} / \mathrm{L}$ sodium diethyl dithiocarbamate and $0.25 \mathrm{mmol} / \mathrm{L}$ nitro-blue tetrazolium. The $\mathrm{O}_{2}{ }^{-}$concentration was presented as $\Delta \mathrm{A}_{540}$ (the variance of $\left.\mathrm{OD}_{540}\right) /(\mathrm{min} \cdot \mathrm{g} \mathrm{FM})$.

\subsection{Measurement of Chlorophyll Contents in Rice Leaves}

The contents of chlorophyll a and b were measured by the colorimetrical method [48]. Briefly, $0.1 \mathrm{~g}$ of rice leaves were homogenized with a $10 \mathrm{~mL}$ mixture solution consisting of acetone and ethanol $(1: 1, v / v)$ for $10 \mathrm{~min}$ in dark. Then, the mixtures were centrifugated at $3000 \times g$ for $20 \mathrm{~min}$. Approximately $2.0 \mathrm{~mL}$ of supernatant was collected for the second centrifugation at $8000 \times g$ for $10 \mathrm{~min}$. Supernatant after twice centrifugation was used for chlorophyll analysis with a UV-Vis. spectrophotometer (Mode 754, Shunyu Hengping Scientific Instrument Co., Ltd., Shanghai, China). $\mathrm{OD}_{663}$ and $\mathrm{OD}_{645}$ were recorded for calculating the contents of chlorophyll $\mathrm{a}$ and $\mathrm{b}$ according to the method of Gassame et al. [48].

\subsection{Activity Measurements of Superoxide (SOD), Catalase (CAT) and Peroxiddase (POD)}

After treatment, rice leaves were collected for analysis of antioxidant enzyme activities, including SOD (EC 1.15.1.1), CAT (EC 1.11.1.6) and POD (EC 1.11.1.7). The extraction procedures were based on the protocol of Fidalgo et al. [49]. The leaf samples were homogenized with pre-cooled $50 \mathrm{mmol} / \mathrm{L} \mathrm{pH7.8} \mathrm{PBS} \mathrm{containing} 5 \mathrm{mmol} / \mathrm{L}$ EDTA and $20 \mathrm{~g} / \mathrm{L}$ polyvinylpyrrolidone in the ratio of $1: 10(w / v)$ in a mortar on ice. The homogenates were centrifugated at $4{ }^{\circ} \mathrm{C}$ with $10,000 \times g$ for $15 \mathrm{~min}$. The supernatant solution was used for activity analysis of POD, CAT and SOD. Particularly, SOD and CAT activities were measured by the method described by Soares et al. [50]. POD activity was measured according to the methods of Fidalgo et al. [49] and Bradford [51].

\subsection{Microscopic Observation of Leaf Slices}

The intact fresh leaves of rice seedlings were rinsed and cut into segments with proper size for embedding and slicing. Rice blade patches were spread horizontally in boiled agar solution that had cooled down to $50^{\circ} \mathrm{C}$ before the agar began solidifying. Rice blade segments embedded by agar were cut to $40 \mu \mathrm{m}$ slices by a microslicer (Zero-1, Dosaka E.M. Co. Ltd., Kyoto, Japan). Then, the slices were observed under a microscope (BX43, Olympus Co., Tokyo, Japan) and the images were captured by a digital camera (MC-50, MShot Co. Ltd., Guangzhou, China) affiliated in a microscope.

\subsection{Statistical Analysis}

All data were analyzed by the SAS ${ }^{\circledR}$ system for Windows (version 2010, SAS Institute, Cary, NC, USA) for multiple-way analysis of variance and Duncan's Multiple Range Test. The results in the figures are presented as means \pm standard error. The significance level was $p=0.05$. 


\section{Results}

\subsection{Effect of Simulated Acid Rain and High Temperature on Rice Height and Biomass}

The height and biomass of rice were measured to investigate their response to acid rain with different $\mathrm{pH}$ under normal- and high-temperature conditions. The results from Figure 1 indicate that $\mathrm{pH} 2$ acid rain treatment inhibited rice growth significantly under both normaland high-temperature conditions. The height and biomass of rice exposed to $\mathrm{pH} 2$ acid rain was $88.2 \%$ and $68.3 \%$ of those after $\mathrm{pH} 7$ treatment under normal-temperature conditions, respectively. Additionally, the corresponding values were $78.0 \%$ and $57.5 \%$ under hightemperature conditions, i.e., high temperature caused greater inhibition after $\mathrm{pH} 2$ acid rain exposure. On the other hand, no remarkable differences in height and biomass were observed among treatments when the $\mathrm{pH}$ of acid rain was over 3 under both temperature conditions except that the biomass after $\mathrm{pH} 3$ acid rain treatment was significantly lower than that of $\mathrm{pH} 7$ rain under high-temperature conditions. Besides, $\mathrm{pH} 5$ acid rain treatment slightly promoted the height of rice plants under both temperature conditions. Analysis of variance indicated that both low- $\mathrm{pH}$ rain and high temperature retarded rice height but only acid rain declined biomass. Notably, their effects were individual, i.e., the interaction effect was not significant.
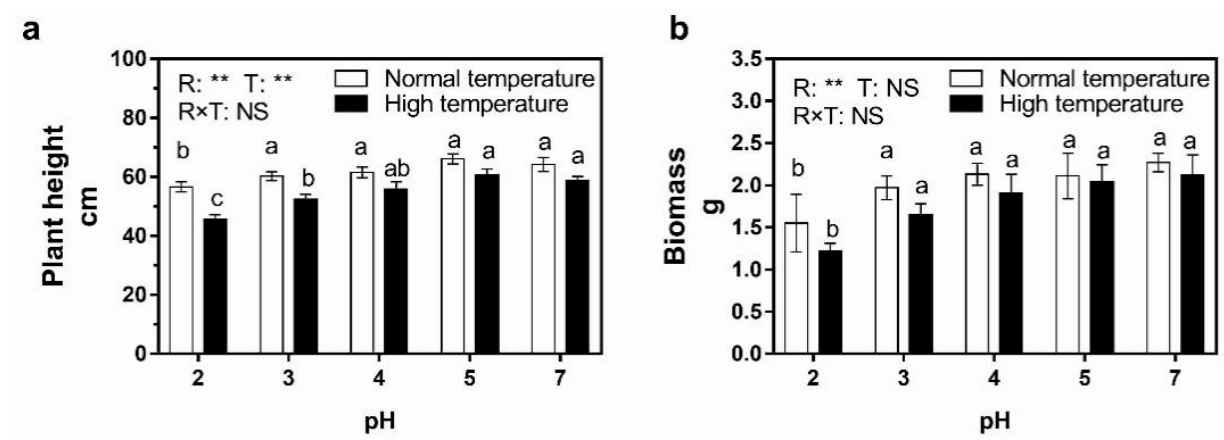

Figure 1. Effect of 7-day simulated acid rain treatment on the growth of rice plants under normaland high-temperature conditions. (a) Plant height. (b) Biomass. The columns with the same letter in each panel indicate an insignificant difference among different treatments $(p<0.05)$. The $p$ values of two-way ANOVA for rain $\mathrm{pH}(\mathrm{R})$, temperature $(\mathrm{T})$ and their interaction $(\mathrm{R} \times \mathrm{T})$ are shown: **,$p \leq 0.01$, NS, $p>0.05$.

All of the rice seedlings grew vigorously in general, and their leaves were green and straight under normal-temperature conditions (Figure 2a-c). Contrarily, rice plants grew weakly with drooping yellow leaves under high-temperature conditions (Figure 2d-f). Particularly, the growth of the plants treated with acid rain at $\mathrm{pH} 2$ and $\mathrm{pH} 3$ was significantly inhibited in comparison to those with higher $\mathrm{pH}$ treatments (Figure 2a,d). The plants with sagging leaves were dwarfed. The phenomenon became more obvious under high-temperature conditions. In addition, exposure to $\mathrm{pH} 2$ acid rain obviously inhibited leaf development. There were seven complete expanded leaves in rice plants after $\mathrm{pH} 7$ treatment, while there were only six slimmer expanded leaves in rice after $\mathrm{pH} 2$ acid rain treatment (Figure 2b,c,e,f). 


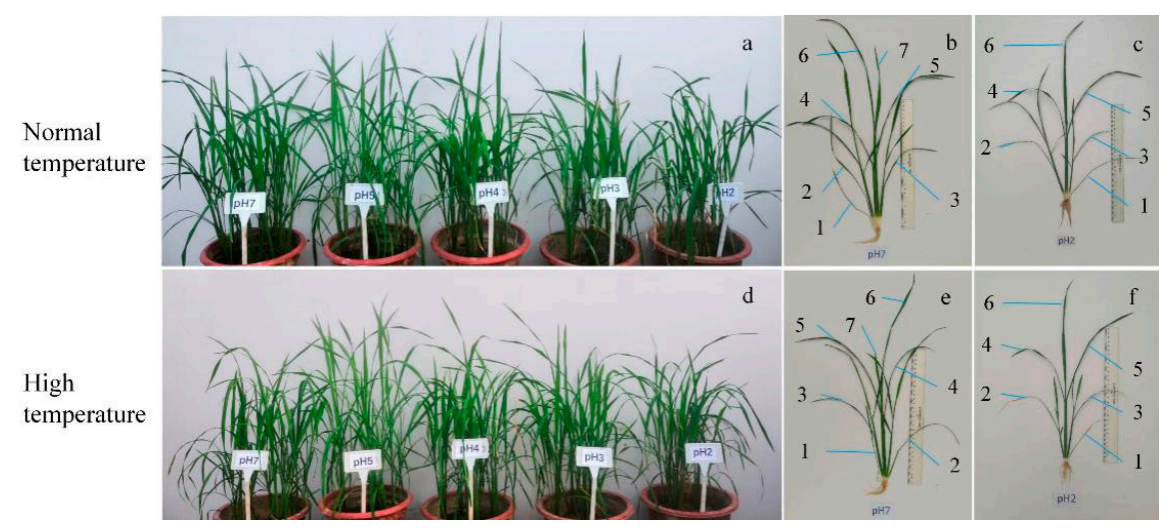

Figure 2. Rice seedlings exposed to different $\mathrm{pH}$ acid rain for 7 days under normal- and hightemperature conditions. (a-c) The seedlings under normal-temperature conditions. (d-f) The seedlings under high-temperature conditions. (a,d) Rice seedlings exposed to acid rain treatments

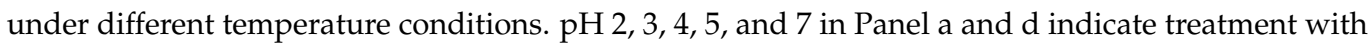
acid rain of $\mathrm{pH} 2,3,4,5$, and deionized water, respectively. (b,e) Seedlings after $\mathrm{pH} 7$ treatment. (c,f) Seedlings after $\mathrm{pH}-2$ treatment. The numbers in the panel $(\mathbf{b}, \mathbf{c}, \mathbf{e}, \mathbf{f})$ indicate complete expanded leaves of seedlings.

\subsection{Effect of Simulated Acid Rain and High Temperature on the Chlorophyll Contents of Rice Leaves}

The potential photosynthesis capacity of leaves can be represented by the chlorophyll contents of rice leaves [52]. The chlorophyll contents of rice leaves declined with the decreasing $\mathrm{pH}$ value of acid rain under both temperature conditions, and the variation trends of chlorophyll a and b contents were similar (Figure 3). In addition, chlorophyll a and $b$ contents under high-temperature conditions were greatly lower than those under normal-temperature conditions. However, no statistically significant declines occurred when treatment $\mathrm{pH}$ was higher than 3. Compared with $\mathrm{pH}-7$ treatment, the contents of chlorophyll $\mathrm{a}$ and $\mathrm{b}$ treated with $\mathrm{pH}-2$ acid rain were reduced by $52.0 \%$ and $39.6 \%$ under normal-temperature conditions and by $61.9 \%$ and $56.1 \%$ under high-temperature conditions, respectively (Figure 3). The significant decreases in chlorophyll contents also occurred in pH-3 acid rain treatments under both temperature conditions. Two-way analysis of variance indicated that both low- $\mathrm{pH}$ rain and high temperature caused a significant decrease $(p<0.01)$ of chlorophyll a content while only acid rain significantly declined chlorophyll $\mathrm{b}$ content. In addition, there was no significant interaction between these two factors.

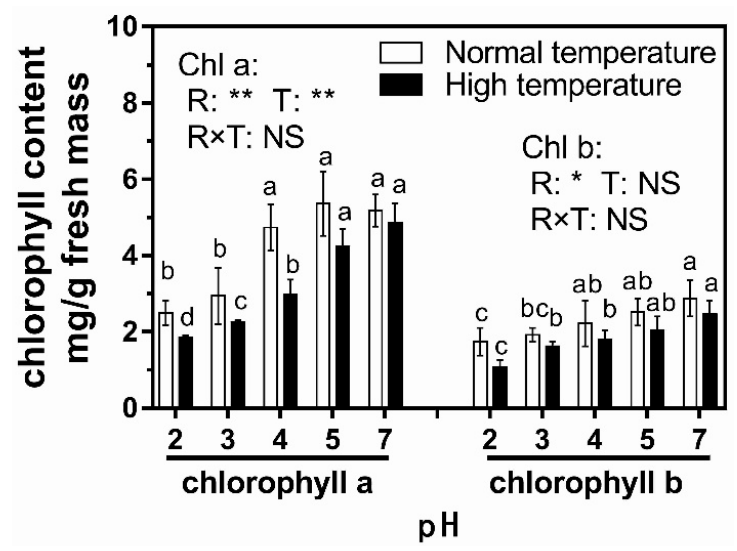

Figure 3. Effect of 7-day simulated acid rain exposure on the chlorophyll content of rice leaves. The same letter followed by the data in the same parameter indicates an insignificant difference among different treatments $(p<0.05)$. The $p$ values of two-way ANOVA for rain $\mathrm{pH}(\mathrm{R})$, temperature $(\mathrm{T})$ and their interaction $(\mathrm{R} \times \mathrm{T})$ are shown: ${ }^{* *}, p \leq 0.01 ;{ }^{*}, p \leq 0.01 ; \mathrm{NS}, p>0.05$. 


\subsection{Effect of Simulated Acid Rain and High Temperature on Leaf Reactive Oxygen Species Concentration and Antioxidant Enzyme Activities}

Reactive oxygen species (ROS), including superoxide anion $\left(\mathrm{O}_{2}{ }^{-}\right)$and hydrogen peroxide $\left(\mathrm{H}_{2} \mathrm{O}_{2}\right)$, are sensitive indices in plants for several stresses. The results from Figure $4 \mathrm{a}, \mathrm{b}$ indicate that the $\mathrm{O}_{2}{ }^{-}$concentrations of leaves subjected to treatments whose $\mathrm{pH}$ was lower than 5 were significantly higher than those with pH-5 or pH-7 treatments, while similar phenomena occurred in $\mathrm{H}_{2} \mathrm{O}_{2}$ concentration when $\mathrm{pH}$ was lower than 4 . Besides, the concentration of both $\mathrm{O}_{2}{ }^{-}$and $\mathrm{H}_{2} \mathrm{O}_{2}$ increased with the decreasing $\mathrm{pH}$ value of acid rain. In comparison to the $\mathrm{pH}-7$ treatment, $\mathrm{pH}-2$ acid rain treatment elevated the concentrations of $\mathrm{O}_{2}{ }^{-}$and $\mathrm{H}_{2} \mathrm{O}_{2}$ in rice leaves by 2.92 times and $84.4 \%$ under normaltemperature conditions and by 2.80 times and $87.2 \%$ under high-temperature conditions, respectively. So, high temperature aggravated the $\mathrm{O}_{2}{ }^{-}$and $\mathrm{H}_{2} \mathrm{O}_{2}$ accumulation in leaves induced by acid rain compared with normal-temperature conditions. Analysis of variance suggested that even though both acid rain and high temperature significantly $(p<0.01)$ increased the concentrations of $\mathrm{O}_{2}{ }^{-}$and $\mathrm{H}_{2} \mathrm{O}_{2}$, there was no remarkable interaction effect between the two factors.

Excessive accumulation of ROS is harmful to cells due to their strong oxidative ability, so the activities of antioxidant enzymes, including superoxide dismutase (SOD), catalase (CAT) and peroxidase (POD), vary as a response. As shown in Figure 4c-e, pH-3 acid rain increased the activities of SOD, CAT and POD by $53.2-83.6 \%$ and $41.9-87.0 \%$ under normal- and high-temperature conditions, respectively, compared to $\mathrm{pH}-7$ treatment under normal-temperature conditions. Notably, $\mathrm{pH}-3$ acid rain increased the activities of SOD, CAT and POD by $43.9-56.3 \%$ under normal-temperature conditions and decreased them by $6.8-31.9 \%$ under high-temperature conditions, respectively. However, the activities of SOD, CAT and POD did not vary greatly among the treatments when the $\mathrm{pH}$ values of acid rain were over 4. Different from height, biomass and chlorophyll contents, rain $\mathrm{pH}$, ambient temperature and their interaction contributed to the variation of enzyme activities on SOD, CAT and POD according to analysis of variance results. But ambient temperature didn't significantly affect SOD activities (Figure 4c-e).

a

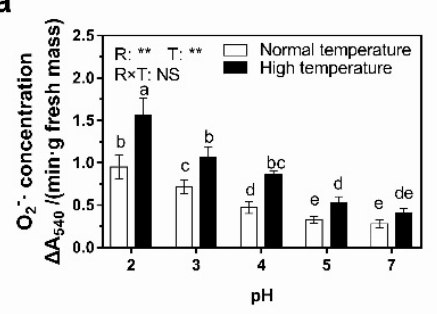

b

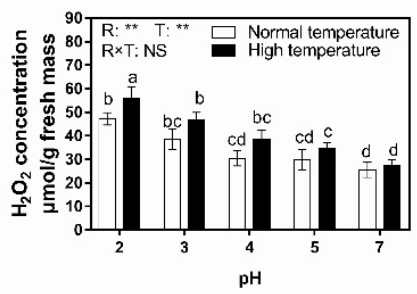

c

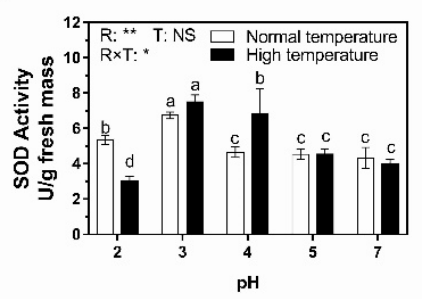

d

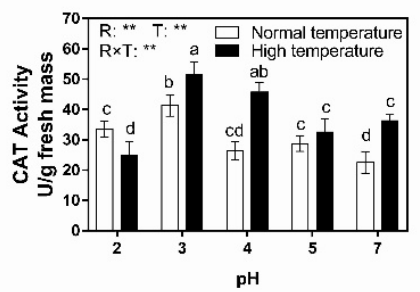

e

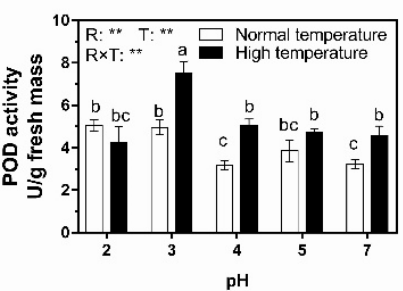

Figure 4. Effect of simulated acid rain and ambient temperature on the activities of antioxidant enzymes and concentrations of reactive oxygen species (ROS) in rice leaves after a 7-day treatment. (a) Superoxide anion $\left(\mathrm{O}_{2}{ }^{-}\right)$concentration. (b) Hydrogen peroxide $\left(\mathrm{H}_{2} \mathrm{O}_{2}\right)$ concentration. (c) Superoxide dismutate (SOD) activity. (d) Catalase (CAT) activity. (e) Peroxidase (POD) activity. The columns with the same letter in each panel indicate an insignificant difference among different treatments $(p<0.05)$. The $p$ values of two-way ANOVA for rain $\mathrm{pH}(\mathrm{R})$, temperature $(\mathrm{T})$ and their interaction $(\mathrm{R} \times \mathrm{T})$ are shown: ${ }^{* *}, p \leq 0.01 ;{ }^{*}, p \leq 0.05 ; \mathrm{NS}, p>0.05$. 


\subsection{Effect of Simulated Acid Rain and Temperature on Rice Leaf Appearance}

Simulated acid rain not only influences physiological responses, but also changes the appearance of plants [53]. Under both temperature conditions, no injury spots appeared in rice leaves treated with $\mathrm{pH}-7$ and $\mathrm{pH}-5$ treatments (Figure $5 \mathrm{a}, \mathrm{b}, \mathrm{f}, \mathrm{g}$ ). Some small necrotic spots only appeared under high-temperature conditions, while they were absent under normal-temperature conditions after suffering from pH-4 acid rain (Figure $5 \mathrm{c}, \mathrm{h}$ ). Even though many yellow or brown spots appeared in rice leaves under both normal- and high-temperature conditions when the acid rain $\mathrm{pH}$ was 2 or 3 , more yellowish white spots (some of them with brown edge) and brown spots were observed in the leaves under hightemperature conditions, and their size was larger than those under normal-temperature conditions (Figure $5 \mathrm{~d}, \mathrm{e}, \mathrm{i}, \mathrm{j}$ ).

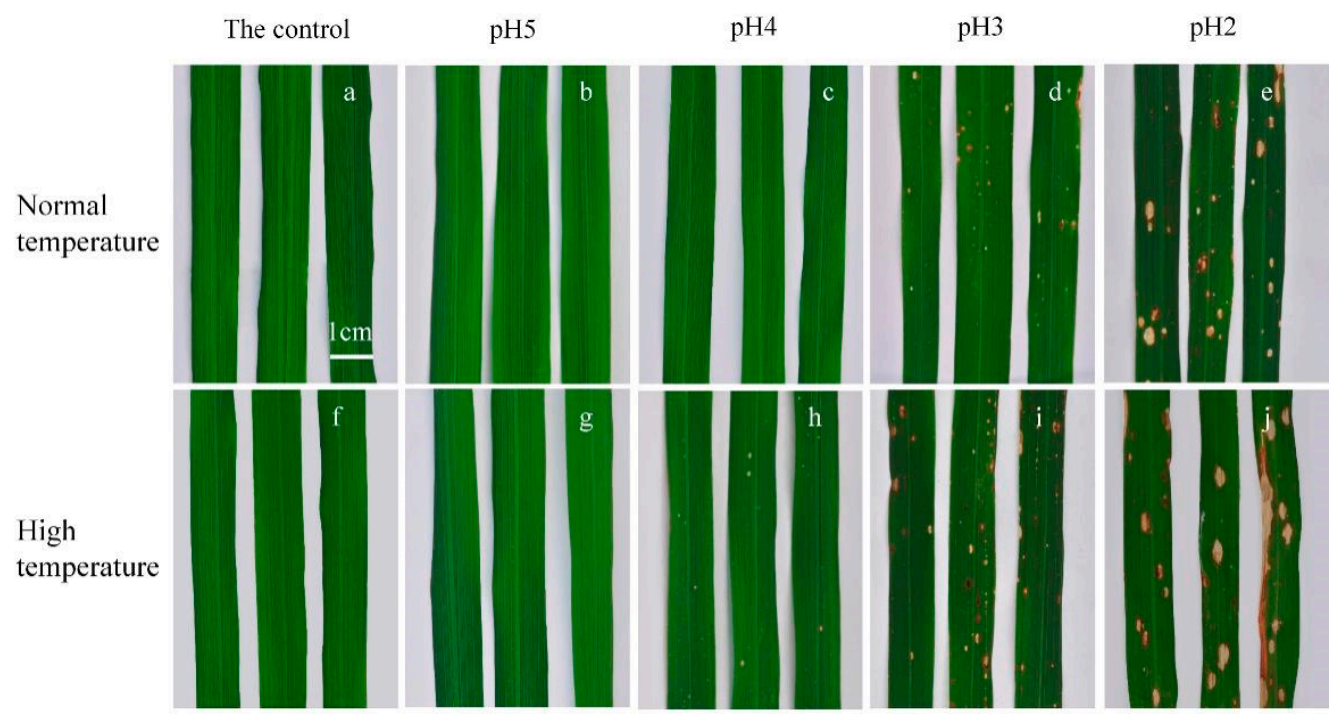

Figure 5. Leaves of rice seedlings exposed to different $\mathrm{pH}$ acid rain for 7 days under normal- and high-temperature conditions. (a-e) The leaves subjected to normal temperature treatment. $(\mathbf{f}-\mathbf{j})$ The leaves subjected to high temperature treatment. (a,f) The leaves with the control ( $\mathrm{pH} 7)$ treatment. $(\mathbf{b}, \mathbf{g})$ The leaves with $\mathrm{pH} 5$ acid rain treatment. (c,h) The leaves with $\mathrm{pH} 4$ acid rain treatment. (d,i) The leaves with $\mathrm{pH} 3$ acid rain treatment. (e,j) The leaves with $\mathrm{pH} 2$ acid rain treatment.

No visible spots were observed on the longitudinal section of rice leaves after being subjected to $\mathrm{pH}-4$ acid rain treatment under normal-temperature conditions, while the injury spots appeared under high-temperature conditions (Figure 6a-c,f-h). After exposure to $\mathrm{pH}-3$ acid rain treatment, many visible injury spots appeared in the longitudinal sections of rice leaves under both normal- and high-temperature conditions, but more injury spots were observed under high-temperature conditions. Besides, more cells losing structural integrity appeared on bulliform cells and minor longitudinal veins away from the midrib (major longitudinal vein) under high-temperature conditions (Figure 6d,i). After pH-2 acid rain treatment, the injuries became more severe, and most of them distributed in bulliform cells, minor longitudinal veins and even midrib. Under high-temperature conditions, the injury spots even crossed two longitudinal veins, and the structural integrity of the vessels and sieve tubes in the minor longitudinal veins could not be maintained (Figure 6e,j). In addition, the damages in leaves at a lower position, e.g., mesophyll between veins, were more severe than those at a higher position. 


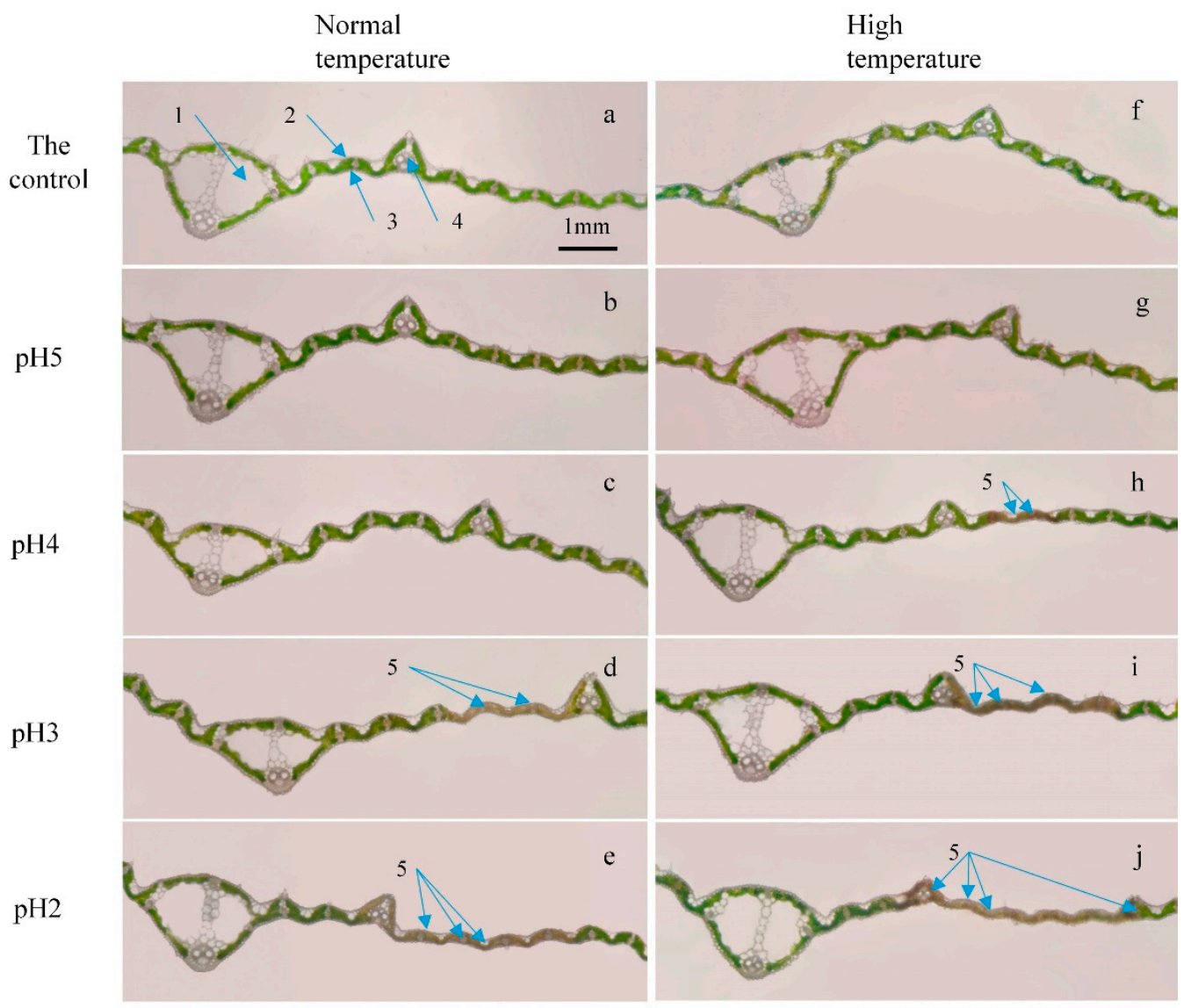

Figure 6. Longitudinal sections of rice leaves treated with different $\mathrm{pH}$ acid rain for 7 days under normal- and hightemperature conditions. (a-e) The leaves subjected to normal temperature treatment. (f-j) The leaves subjected to high temperature treatment. (a,f) The leaves with the control (pH 7) treatment. $(\mathbf{b}, \mathbf{g})$ The leaves with $\mathrm{pH} 5$ acid rain treatment. (c,h) The leaves with $\mathrm{pH} 4$ acid rain treatment. (d,i) The leaves with $\mathrm{pH} 3$ acid rain treatment. (e,j) The leaves with pH 2 acid rain treatment. Labels in microscopic image: 1 , major longitudinal vein; 2 , upper epidermis; 3 , lower epidermis; 4 , minor longitudinal vein; 5 , injury spots.

3.5. Physiological Alleviating Effect of AOS on High Temperature-Low pH Compound Stress on Leaves

Seven-day foliar spraying AOS significantly increased rice plant biomass after $\mathrm{pH}-3$, -5 and -7 treatments under high-temperature conditions, and the increasing percentages ranged from $2.0 \%$ to $9.7 \%$. Besides, the application of AOS recovered the biomass of plants subjected to a high temperature to at least $73.0 \%$ of the corresponding values under normaltemperature conditions (Table 1). Under normal-temperature conditions, chlorophyll a content only insignificantly raised $1.6-14.2 \%$ after applying AOS, while a significant increment occurred in chlorophyll $\mathrm{b}$ contents after $\mathrm{pH}-2,-4$ and -5 treatments, which ranged from $-1.1 \%$ to $38.4 \%$ (Figure 7). Under high-temperature conditions, applying AOS alleviated the acid-rain-induced decline of chlorophyll a content in leaves when the $\mathrm{pH}$ of acid rain treatment was over 3 . The increasing ratio ranged from $26.0 \%$ to $67.8 \%$. Moreover, the chlorophyll a contents of leaves subjected to high-temperature treatment remained at $91.7 \%$ to $118 \%$ of those with corresponding $\mathrm{pH}$ treatments under normal-temperature conditions after AOS treatment (Figure 7). On the other hand, spraying AOS remarkably increased chlorophyll $\mathrm{b}$ concentration in leaves after all acid rain $(\mathrm{pH} \leq 5)$ treatments (Figure 7) under both normal- and high-temperature conditions, which was different from the results of Figure 7. The increasing ratio ranged from $4.14 \%$ to $10.6 \%$. Besides, applying AOS recovered chlorophyll $\mathrm{b}$ contents under high-temperature conditions to at least $84.8 \%$ of corresponding values in normal-temperature conditions. It can be summarized that 
applying AOS induced a satisfactory alleviation effect in maintaining chlorophyll contents when the leaves were exposed to acid rain whose $\mathrm{pH}$ was higher than 3 . Analysis of variance indicated that temperature, rain $\mathrm{pH}$ and AOS application all significantly $(p<0.01)$ affected the contents of both chlorophyll component. There were also significant interaction effects among three factors, but with some exceptions.

Table 1. Effect of alginate oligosaccharides (AOS) fertilizer on plant biomass for 7-day high temperature-low $\mathrm{pH}$ compound stress on leaf.

\begin{tabular}{|c|c|c|}
\hline \multirow{2}{*}{ Treatment } & \multicolumn{2}{|c|}{ Biomass (g Plant $^{-1}$ ) } \\
\hline & Without AOS & With AOS \\
\hline $\mathrm{pH} 2$ & $1.20 \pm 0.02 \mathrm{~g}^{*}$ & $1.31 \pm 0.02 \mathrm{f}$ \\
\hline $\mathrm{pH} 3$ & $1.31 \pm 0.03 \mathrm{f}$ & $1.44 \pm 0.02 \mathrm{e}$ \\
\hline $\mathrm{pH} 4$ & $1.56 \pm 0.01 \mathrm{~d}$ & $1.59 \pm 0.01 \mathrm{~d}$ \\
\hline $\mathrm{pH} 5$ & $1.65 \pm 0.06 \mathrm{~d}$ & $1.80 \pm 0.06 \mathrm{c}$ \\
\hline $\mathrm{pH} 7$ & $2.09 \pm 0.04 b$ & $2.29 \pm 0.02 \mathrm{a}$ \\
\hline
\end{tabular}

* The same letter followed by the data in the same column indicates an insignificant difference among different treatments $(p<0.05)$.

a

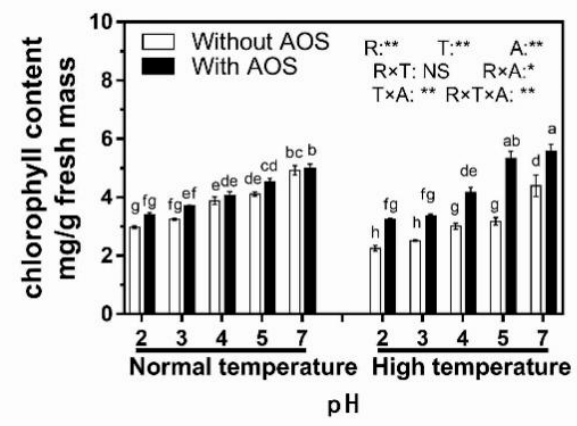

b

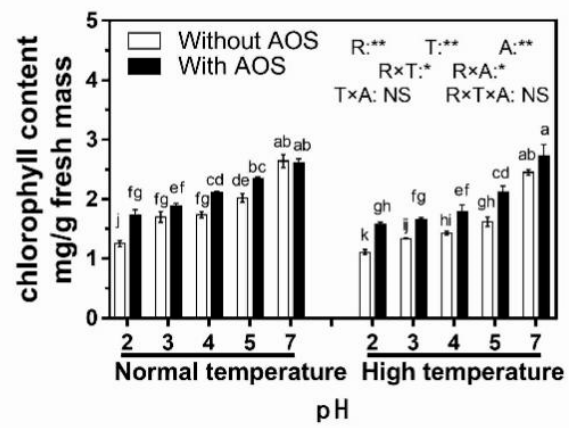

Figure 7. Effect of alginate oligosaccharides (AOS) in chlorophyll a and b contents of leaves subjected to low $\mathrm{pH}$ stress at different temperatures for 7 days. (a) Chlorophyll a. (b). Chlorophyll b. The same letter followed by the data in the same parameter indicates an insignificant difference among different treatments $(p<0.05)$. The $p$ values of three-way ANOVA for rain $\mathrm{pH}(\mathrm{R})$, temperature $(\mathrm{T})$, $\operatorname{AOS}(\mathrm{A})$ and their interaction $(\mathrm{R} \times \mathrm{T}, \mathrm{R} \times \mathrm{A}, \mathrm{T} \times \mathrm{A}, \mathrm{R} \times \mathrm{T} \times \mathrm{A})$ are shown: ${ }^{* *}, p \leq 0.01{ }^{*}, p \leq 0.05$; NS, $p>0.05$.

AOS remarkably declined $\mathrm{O}_{2}{ }^{-}$concentration by $22.4 \%$ to $56.1 \%$ compared to those without AOS when plants were exposed to acid rain whose $\mathrm{pH}$ was higher than 3 under high temperature, which were 0.86 to 1.57 times of corresponding values under normaltemperature conditions (Figure 8a). Event AOS could not reverse the increasing trend of $\mathrm{H}_{2} \mathrm{O}_{2}$ concentration when leaves were exposed to acid rain, and foliar applying AOS declined $\mathrm{H}_{2} \mathrm{O}_{2}$ concentration by $4.5 \%$ to $17.2 \%$ compared to those subjected to acid rain of corresponding $\mathrm{pH}$ but without AOS treatments, which was most significant after $\mathrm{pH}-2$ treatment. Besides, AOS reduced $\mathrm{H}_{2} \mathrm{O}_{2}$ concentration to the levels closed to corresponding $\mathrm{pH}$ ones after $\mathrm{pH}-2,-3$ and -7 rain treatments under normal conditions (Figure $8 \mathrm{~b}$ ).

SOD activities increased when the leaves were exposed to acid rain $(\mathrm{pH}<5)$ treatments, and the highest activities were observed in $\mathrm{pH}-3$ treatment when AOS was absent. In addition, SOD activities of leaves with AOS treatment also kept a stable level when leaves were exposed to acid rain, which were significantly higher than the activity after pH-7 treatment (Figure 8c). So, SOD activities of leaves with AOS treatment were higher than those of corresponding treatments without AOS treatment when leaves were exposed to rain with a $\mathrm{pH}$ of 2 and 5 . However, opposite results happened when the $\mathrm{pH}$ of acid rain was 3. On the other hand, AOS significantly increased CAT and POD activities of leaves in case of $\mathrm{pH}-2$ to -4 treatments by $13.1 \%$ to $50.4 \%$ and $10.7 \%$ to $20.6 \%$, respectively 
(Figure 8d,e). Nevertheless, the POD activities of leaves with AOS treatment were approximately equal to or even lower than those without AOS treatment when the $\mathrm{pH}$ of rain was higher than 5. However, the CAT activities after AOS treatment were still slightly higher than those without AOS on this occasion. Compared with the corresponding values without AOS under normal conditions, CAT and POD activities of leaves subjected to AOS under high temperature increased by $1.9 \%$ to $74.8 \%$ and $12.0 \%$ to $55.6 \%$, respectively.

a

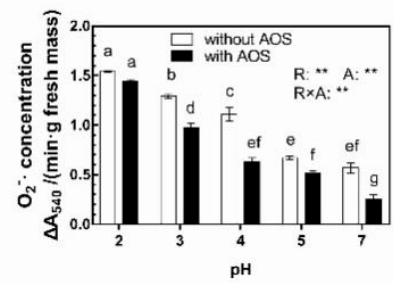

C

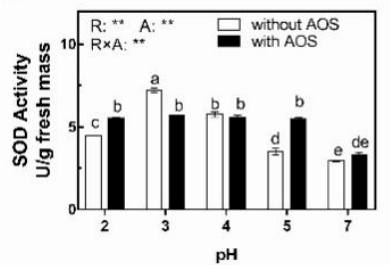

d

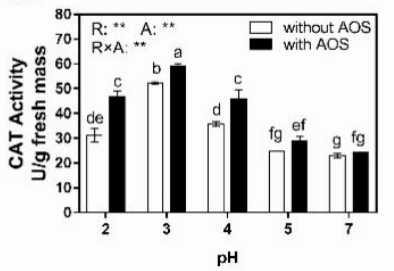

b

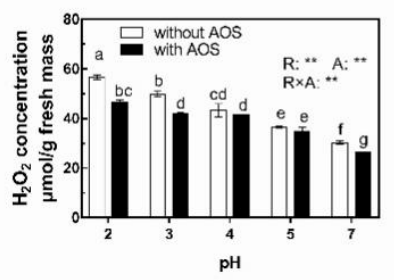

e

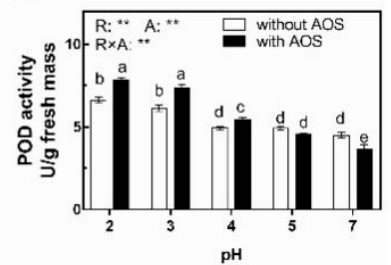

Figure 8. Effect of AOS in antioxidant enzyme activities and concentrations of reactive oxygen species and of leaves subjected to 7-day high temperature-low $\mathrm{pH}$ compound stress. (a) Superoxide anion $\left(\mathrm{O}_{2}{ }^{-} \cdot\right)$ concentration. (b) Hydrogen peroxide $\left(\mathrm{H}_{2} \mathrm{O}_{2}\right)$ concentration. (c) Activity of superoxide dismutate (SOD). (d) Activity of peroxidase (POD). The columns with the same letter in each panel indicate an insignificant difference among different treatments $(p<0.05)$. The $p$ values of two-way ANOVA for rain $\mathrm{pH}(\mathrm{R}), \operatorname{AOS}(\mathrm{A})$ and their interaction $(\mathrm{R} \times \mathrm{A})$ are shown: ${ }^{* *}, p \leq 0.01 ;{ }^{*}, p \leq 0.05$; NS, $p>0.05$.

\subsection{Alleviating Effect of Foliar AOS Application on Structural Damages Induced by High Temperature-Low pH Compound Stress on Leaves}

No visible symptom appeared on the leaves when the rain $\mathrm{pH}$ treatment was over 5 , regardless of whether AOS was applied or not (Figure 9). On the contrary, chlorotic spots and strips were observed on the leaf blade surface after $7 \mathrm{~d} \mathrm{pH}-4$ acid rain treatment when AOS was absent, while the corresponding leaves after AOS treatment were as healthy as those after the control ( $\mathrm{pH} 7)$ treatment. After $\mathrm{pH}-3$ acid rain treatment, not only chlorotic but also brown and even transparent spots and strips were widely distributed on leaf blades without AOS treatment, but only a few small yellow spots appeared on the leaves after AOS treatment. Similarly, the sizes of brown and transparent spots on leaves without AOS treatment were larger than those with AOS treatment after $\mathrm{pH}-2$ acid rain exposure.

The microscopic photos (Figure 10) indicated that AOS prevented leaves from suffering visible damage when acid rain $\mathrm{pH}$ was higher than 5 . On the other hands, a few chlorotic spots appeared in upper epidermis after $\mathrm{pH}-5$ treatment without AOS. When the $\mathrm{pH}$ of acid rain continued decreasing, damage spots appeared on leaves of both AOS-present and -absent treatments. However, the spots on the leaves with AOS treatment were less than the corresponding ones without AOS treatment when acid rain $\mathrm{pH}$ was 3 or 4 . It is worth mentioning that the necrosis area expanded to the mesophyll of leaves when they were subjected to treatments without AOS, while only a brown area appeared at the epidermis of leaves with AOS treatment. Irrespective of this, necrotic tissues were observed in epidermis, mesophyll and minor longitudinal veins of leaf blades when they suffered from $\mathrm{pH}-2$ acid rain, and there was little difference between AOS-present and -absent treatments. So, it can be summarized that applying AOS significantly alleviated the damages caused by acid rain $(\mathrm{pH} \geq 3)$ and high temperature on leaf blade tissue. 


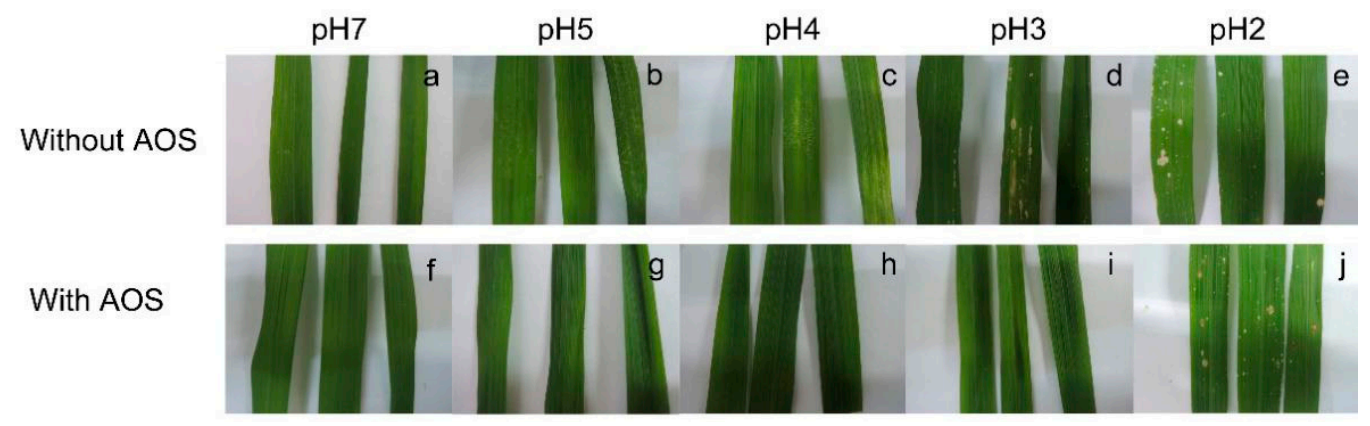

Figure 9. Leaves of rice seedlings exposed to different $\mathrm{pH}$ acid rain with and without foliar applying AOS for 7 days. (a-e) The leaves subjected to normal temperature treatment. $(\mathbf{f}-\mathbf{j})$ The leaves subjected to high temperature treatment. $(\mathbf{a}, \mathbf{f})$ The leaves with the control ( $\mathrm{pH} 7)$ treatment. $(\mathbf{b}, \mathbf{g})$ The leaves with $\mathrm{pH} 5$ acid rain treatment. (c,h) The leaves with pH 4 acid rain treatment. $(\mathbf{d}, \mathbf{i})$ The leaves with $\mathrm{pH} 3$ acid rain treatment. $(\mathbf{e}, \mathbf{j})$ The leaves with $\mathrm{pH} 2$ acid rain treatment.

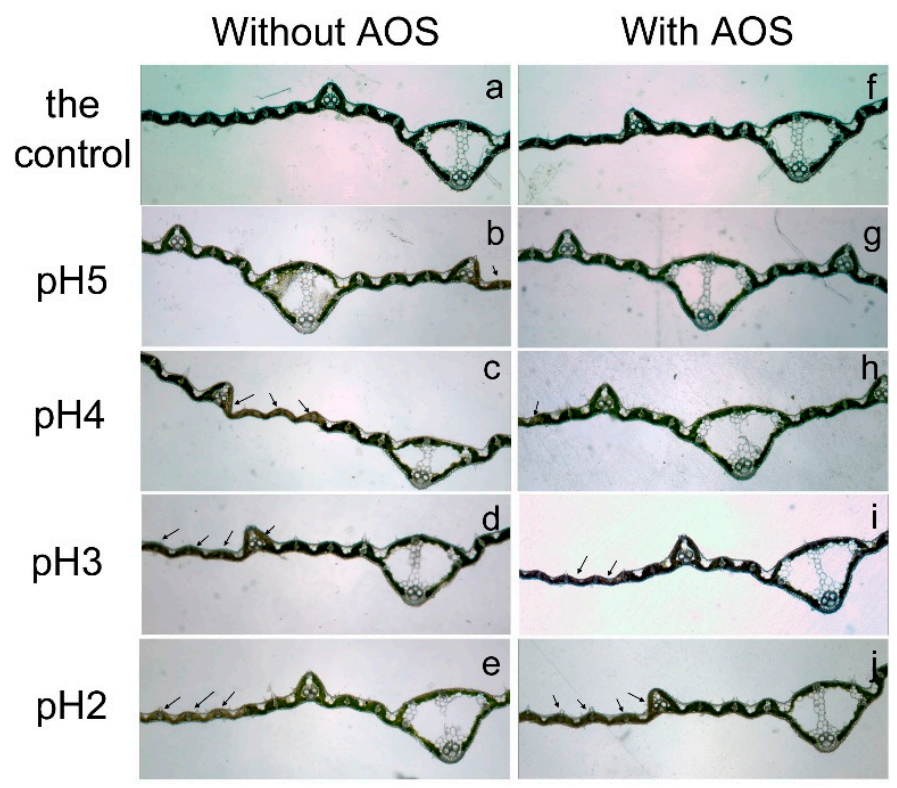

Figure 10. Longitudinal sections of rice leaves treated with different $\mathrm{pH}$ acid rain with and without foliar applying AOS for 7 days. Injury spots in the leaf blade were indicated by arrows. (a-e) The leaves subjected to normal temperature treatment. $(\mathbf{f}-\mathbf{j})$ The leaves subjected to high temperature treatment. (a,f) The leaves with the control $(\mathrm{pH} 7)$ treatment. $(\mathbf{b}, \mathbf{g})$ The leaves with $\mathrm{pH} 5$ acid rain treatment. (c,h) The leaves with $\mathrm{pH} 4$ acid rain treatment. (d,i) The leaves with $\mathrm{pH} 3$ acid rain treatment. $(\mathbf{e}, \mathbf{j})$ The leaves with $\mathrm{pH} 2$ acid rain treatment.

\section{Discussion}

\subsection{Effect of Simulated Acid Rain on ROS Concentrations and Activities of Antioxidant Enzymes} in Rice Leaves

Various ROS are produced and accumulate in plants when they are suffering from abiotic stresses $[7,10]$. In this study, the threshold $\mathrm{pH}$ value of significant increment for $\mathrm{O}_{2}{ }^{-}$ concentrations and $\mathrm{H}_{2} \mathrm{O}_{2}$ concentration in leaves were 4 and 3, respectively (Figure $4 a, b$ ), which indicates that that rice leaves can partially cope with oxidative stress resulting from $\mathrm{pH}-4$ to $\mathrm{pH}-5$ acid rain treatment by self-regulation in rice leaves (Figures 1-3 and 5-7). Ren et al. also reported similar results that simulated acid rain ranging from $\mathrm{pH} 3.5$ to 5.5 does not induce damage spots [10]. However, strong acid rain ( $\mathrm{pH} 2)$ triggered excessive $\mathrm{O}_{2}{ }^{-}$. and $\mathrm{H}_{2} \mathrm{O}_{2}$ accumulation in rice leaves (Figure $4 \mathrm{a}, \mathrm{b}$ ) and resulted in distinguishing irreversible injury symptoms (Figures 6 and 7) partially since its acidity exceeded the ROS scavenging ability of rice plants, especially under high-temperature conditions.

To alleviate oxidative damage triggered by ambient stresses, plants have developed a series of physiological mechanisms for adaption [54]. For example, plants evolve an- 
tioxidant enzymes, including SOD, CAT, POD, etc., to regulate the ROS accumulation and reduce the damages caused by various stresses. In particular, $\mathrm{SOD}$ converts $\mathrm{O}_{2}{ }^{-}$into $\mathrm{H}_{2} \mathrm{O}_{2}$ and $\mathrm{O}_{2}$, and subsequently CAT and POD efficiently catalyze $\mathrm{H}_{2} \mathrm{O}_{2}$ into completely harmless water [52]. Activity elevation of antioxidant enzymes is a strategy for plants to cope with acid rain [2] and high temperature tolerance [55], and Ren et al. [10] and Gilani et al. [56] summarized that $\mathrm{pH} 3.5$ is the threshold value of antioxidant enzyme activity elevation for several plants. Even the activities of SOD, POD and CAT did not vary greatly among treatments when the $\mathrm{pH}$ of acid rain was over 4 under both temperature conditions, strong acid rain ( $\mathrm{pH} 2$ or 3 ) remarkably interfered with functions of these enzymes, and high-temperature treatment aggravated this problem (Figure 4c,e). Notably, the activities of SOD, POD, and CAT in rice leaves were raised by $\mathrm{pH}-3$ acid rain treatment, while they were reduced by $\mathrm{pH}-2$ acid rain under high-temperature conditions (Figure $4 \mathrm{c}, \mathrm{e})$. The results suggested that the ROS production triggered by $\mathrm{pH}-2$ acid rain might exceed the scavenging abilities of antioxidant enzymes, especially under high-temperature conditions. It also explained the ROS accumulation discussed above. However, it is worth noting that the injury degree of high temperature depends on exposure duration and intensity [20]. Compared with severe heat (over $40^{\circ} \mathrm{C}$ ) stress, the high temperature in this study was relatively mild [16], so its damaging effect was easily concealed by acid rain.

\subsection{The Damages of Simulated Acid Rain on Rice Leaves}

Apart from invisible physiological changes, acid rain also causes visible changes in plants. Similar to the results of leaves subjected to rain whose $\mathrm{pH}$ was higher than 4 (Figures 5 and 6), Ren et al. found that 5-time $\mathrm{pH}-4$ acid rain exposure does not lead to obvious damages on rice leaves [10]. On the other hand, Rodrigues et al. [57] and Liang et al. [11] reported that visible chlorotic spots appeared on the leaves after being exposed to $\mathrm{pH}-2$ or $\mathrm{pH}-3$ acid rain. Besides, high-temperature conditions aggravate this injury [58]. These results were consistent with those of Figure 5 that $\mathrm{pH}-2$ and $\mathrm{pH}-3$ acid rain caused significant necrotic damages in rice leaves under both temperature conditions, and the symptoms were more severe under high-temperature conditions. Satoh et al. [59] reported that $7 \mathrm{~d}$ acidic fog exposure depresses chlorophyll synthesis and, subsequently leads to leaf chlorosis, which is another significant acid-rain-induced symptom [13]; this happens due to ROS accumulation and chlorophyll contents declining. Besides, the variation of chlorophyll contents (Figure 3) coincided with the report from Huang et al. [45] that the chlorphyll a contents of leaves were sensitive to acid rain $\mathrm{pH}$ while chlorophyll b content kept stable, which is regarded as a strategy to avoid leaf senescence and chlorophyll decomposition. Ren et al. suggested that $\mathrm{pH}-2.5$ or -3.0 simulated acid rain triggers increases in malondialdehyde concentration and membrane permeability, and subsequently induced injures on leaves [10]. Considering the results of ROS and antioxidant enzyme activities (Figure 4), it is reasonable to assume that the leaf chlorosis after strong acid rain exposure was attributed to ROS accumulation. It is worth mentioning that the occurrence of visible necrotic spots induced by acid rain depended on the intensity and exposure duration of acid rain. Li et al. [60] indicated that acid-rain-induced damages in rice leaves can be detected within minutes. However, in this study, injury spots appeared within 4 to $5 \mathrm{~h}$ after $\mathrm{pH}-2$ acid rain exposure under normal-temperature conditions, and 3 to $4 \mathrm{~h}$ under high-temperature conditions (data not shown).

Ju et al. [61] found that the chloroplasts of rice leaves keep an intact structure when they were treated with $\mathrm{pH}-4$ acid rain, while they swell when they are treated with $\mathrm{pH}-3$ acid rain. Similarly, thylakoid and matrix lamellar structures in rice leaves are deformed, accompanying cell membrane fracture and chloroplast matrix leakage after exposure to $\mathrm{pH}-$ 2 acid rain [53]. Moreover, Vani et al. indicated that in vivo high temperature $\left(40^{\circ} \mathrm{C}\right) \mathrm{can}$ alter chloroplast and thylakoid ultrastructures of rice leaves [58]. The results from Figure 7 support the above views that spraying $\mathrm{pH}-2$ and -3 acid rain resulted in obvious damages in upper and lower epidermal tissues, bulliform cells, aerial cavity, mesophyll, vascular bundles and parenchymal tissues [62]. Irrespective of this, $\mathrm{pH}-4$ acid rain only slightly 
injured the upper epidermal cells under high-temperature conditions. Taken together, the above results suggest that low-pH acid rain could trigger injures on rice leaves, and high temperature stress aggravated this damage. Since chloroplasts were damaged, chlorophyll contents declined. Subsequently, the growth and development of rice were seriously retarded (Figures 1-3). It was an interesting finding that acid rain preferentially damaged the parts far from the aerial cavities of the blade (Figure 7). The probable reason for this is that acid rain is inclined to accumulate on the lower position between the veins of a leaf rather than the higher position with aerial cavities after acid rain exposure.

\subsection{Alginate Oligosaccharide Alleviated Symptoms Induced by Acid Rain and High Temperature}

The results of Figure 8 indicate that AOS can alleviate the ROS accumulation and enhance antioxidant enzyme activities in leaves induced by both acid rain and high temperature. However, available direct evidence from systemic studies on the alleviating effect of AOS on acid rain and high temperature is still limited. So, its alleviating effect has to be discussed with the results and opinions of studies on other stresses, e.g., acidic fog, pathogen infection and drought.

Nutrient solution with $20 \mathrm{mg} / \mathrm{L}$ AOS is reported to enhance auxin synthesis, accumulation and transport, and subsequently promotes root elongation growth in rice root [27]. Similarly, applying AOS on the leaves of flowering Chinese cabbage (Brassica campestris L. ssp. Chinensis var. utilis Tsen et Lee) enhances gibberellic acid and trans-zeatin riboside transport in shoot [63]. Moreover, submicroparticles containing alginate significantly promote wheat growth by up-regulating auxin synthesis, transport and metabolism-related genes and, subsequently, increase auxin content [38]. In addition, AOS is reported to bind with guard cells in stomata and increases stomatal conductance $[41,64]$. The above studies partially explain the mechanism of the increases in biomass and chlorophyll contents after AOS treatment (Table 1, Figure 7). It is worth noting that there were interactions among rain $\mathrm{pH}$, temperature and AOS on chlorophyll contents (Figure 7). So, the value variation in Table 1 and Figure 7 might be the result of a synergistic effect among these three factors. For instance, Figure 7 suggests that high temperature decreased chlorophyll a contents, but the chlorophyll a contents of leaves subjected to $\mathrm{pH}-7$ and $\mathrm{pH}-5$ rain treatments under high-temperature conditions with applying AOS were higher than not only corresponding treatments without applying AOS under high-temperature conditions, but also those under normal-temperature conditions (Figure 7). This phenomenon demonstrates that high temperature may be a positive factor for chlorophyll a accumulation when AOS and neutral-to-mild acidic rain ( $\mathrm{pH}$ higher than 5) exit simultaneously.

Apart from contributing to chlorophyll contents, it is reported that AOS can increase the activities of the SOD and POD of wheat (Triticum aestivum L.) leaves [35] as well the SOD, CAT and POD activities of tomatoes (Lycopersicon esculentum Mill.) [65] subjected to drought. In this study, both high temperature [17] and acid rain [66] are triggers of ROS (Figure 4), while AOS enhance the antioxidant capacity of plant to scavenger ROS [38] by triggering antioxidant enzyme synthesis [67] (Figure 8). Similarly, AOS also elevated the CAT and POD activities of rice exposed to pathogen infection [68] and wheat exposed to cadmium [67]. It is worth paying attention to the fact that the contribution of AOS for SOD seems to be just keeping its activity at a relatively high level while remarkably elevating CAT and POD activities with decreasing acid rain $\mathrm{pH}$ (Figure $8 \mathrm{c}-\mathrm{e}$ ). As a result, the $\mathrm{O}_{2}{ }^{-}$concentration of a leaf with AOS treatment reached a similar level to that without AOS, while the $\mathrm{H}_{2} \mathrm{O}_{2}$ concentration with AOS treatment was still lower than that without $\mathrm{AOS}$ when acid rain $\mathrm{pH}$ was 2 (Figure $8 \mathrm{a}, \mathrm{b}$ ). As a result of antioxidant enzyme activity being raised or maintained to a relatively high level and ROS being scavenged, the cellular membrane was protected from the damage of ROS [65], and $\mathrm{H}_{2} \mathrm{O}_{2}$-induced cell death was avoided [69]. Therefore, the contribution of AOS on the raising of CAT and POD activities, maintaining SOD activity as well as scavenging $\mathrm{H}_{2} \mathrm{O}_{2}$ and $\mathrm{O}_{2}{ }^{-}$(Figure 8) probably helps leaves with AOS treatments recovering from the compound stress of acid rain and high temperature. Moreover, direct interaction with the plasma membrane is 
another mechanism of AOS promoting plant growth [70]. As the comprehensive effect of AOS on chlorophyll synthesis, ROS scavenging and direct membrane interaction, the cell damage and subsequent leaf chlorosis were alleviated (Figures 9 and 10). However, it is worth noting that AOS are potential stimulators for endogenous stress-resistant compounds accumulating in plants $[35,71]$, so there may be some unknown secondary resistant mechanisms activated by AOS, which need to be elucidated in further study.

\section{Conclusions}

Low-pH acid rain induced the variation of the activities of antioxidant enzymes in rice, the accumulation of $\mathrm{H}_{2} \mathrm{O}_{2}$ and $\mathrm{O}_{2}{ }^{-}$, and reduced the contents of chlorophyll. Subsequently, the epidermal cells, mesophyll cells and minor longitudinal veins were damaged. High temperature aggravated the damage of low-pH acid rain on rice leaves with higher ROS concentrations and more necrotic spots with a punctate structure. The foliar application of AOS alleviated the above symptoms by maintaining or enhancing SOD, CAT and POD activities to scavenge $\mathrm{H}_{2} \mathrm{O}_{2}$ and $\mathrm{O}_{2}{ }^{-}$. As a result, the biomass and chlorophyll contents of rice were recovered and the structural integrity of leaf tissue was maintained.

Author Contributions: Conceptualization and project administration, J.Z. and H.S.; methodology, validation and supervision, H.S., X.-J.Y. and S.M.; formal analysis, X.-J.Y.; investigation and resources, Y.C. and Z.H.; data curation, X.-J.Y., Y.C. and Z.H.; writing-original draft preparation, Y.C. and Z.H.; writing-review and editing, X.-J.Y., and H.S.; visualization, X.-J.Y., Y.C. and Z.H.; funding acquisition, J.Z. All authors have read and agreed to the published version of the manuscript.

Funding: This research was funded by the National Natural Science Foundation of China, grant number U1701236, the Science and Technology Planning Project of Guangdong, Project, grant number 2019B030301007 and the National Key Research and Development Program of China, grant number 2019B030301007.

Data Availability Statement: Not applicable.

Conflicts of Interest: The authors declare no conflict of interest. The funders had no role in the design of the study; in the collection, analyses, or interpretation of data; in the writing of the manuscript, or in the decision to publish the results.

\section{References}

1. Alexieva, V.; Ivanov, S.; Sergiev, I.; Karanov, E. Interaction between stresses. Bulg. J. Plant Physiol. 2003, 29, 1-17, Special Issue: Proceedings of the European Workshop ESSA.

2. Shu, X.; Zhang, K.R.; Zhang, Q.F.; Wang, W.B. Ecophysiological responses of Jatropha curcas L. seedlings to simulated acid rain under different soil types. Ecotoxicol. Environ. Safe. 2019, 185, 109705. [CrossRef]

3. Singh, A.; Agrawal, M. Acid rain and its ecological consequences. J. Environ. Biol. 2008, 29, $15-24$.

4. Zheng, F.W.; Rao, W.B.; Chu, X.D.; Bai, H.; Jiang, S.Y. Chemical and sulfur isotopic characteristics of precipitation in a representative urban site, South China: Implication for anthropogenic influences. Air Qual. Atmos. Health 2020, 13, 349-359. [CrossRef]

5. Debnath, B.; Irshad, M.; Mitra, S.; Li, M.; Rizwan, H.M.; Liu, S.; Pan, T.; Qiu, D. Acid rain deposition modulates photosynthesis, enzymatic and non-enzymatic antioxidant activities in tomato. Int. J. Environ. Res. 2018, 12, 203-214. [CrossRef]

6. Liu, X.; Fu, Z.; Zhang, B.; Zhai, L.; Meng, M.; Lin, J.; Zhuang, J.; Wang, G.G.; Zhang, J. Effects of sulfuric, nitric, and mixed acid rain on Chinese fir sapling growth in Southern China. Ecol. Environ. Safe. 2018, 160, 154-161. [CrossRef]

7. Ma, Y.D.; Wang, B.; Zhang, R.; Gao, Y.; Zhang, X.; Li, Y.; Zuo, Z. Initial simulated acid rain impacts reactive oxygen species metabolism and photosynthetic abilities in Cinnamonum camphora undergoing high temperature. Ind. Crop. Prod. 2019, 135, 352-361. [CrossRef]

8. Cape, J.N. Direct damage to vegetation caused by acid rain and polluted cloud: Definition of critical levels for forest trees. Environ. Pollut. 1993, 82, 167-180. [CrossRef]

9. Ramlall, C.; Varghese, B.; Ramdhani, S.; Pammenter, N.W.; Bhatt, A.; Berjak, P. Sershen Effects of simulated acid rain on germination, seedling growth and oxidative metabolism of recalcitrant-seeded Trichilia dregeana grown in its natural seed bank. Physiol. Plant. 2015, 153, 149-157. [CrossRef]

10. Ren, X.; Zhu, J.; Liu, H.; Xu, X.; Liang, C. Response of antioxidative system in rice (Oryza sativa) leaves to simulated acid rain stress. Ecotoxicol. Environ. Safe. 2018, 148, 851-856. [CrossRef]

11. Liang, C.; Ma, Y.; Li, L. Comparison of plasma membrane $\mathrm{H}^{+}$-ATPase response to acid rain stress between rice and soybean. Environ. Sci. Pollut. Res. 2020, 27, 6389-6400. [CrossRef] [PubMed] 
12. Liang, C.; Ge, Y.; Su, L.; Bu, J. Response of plasma membrane $\mathrm{H}^{+}$-ATPase in rice (Oryza sativa) seedlings to simulated acid rain. Environ. Sci. Pollut. Res. 2015, 22, 535-545. [CrossRef]

13. Ju, S.; Wang, L.; Chen, J. Effects of silicon on the growth, photosynthesis and chloroplast ultrastructure of Oryza sativa L. seedlings under acid rain stress. Silicon 2020, 12, 655-664. [CrossRef]

14. Du, J.; Qv, M.; Zhang, Y.; Cui, M.; Zhang, H. Simulated sulfuric and nitric acid rain inhibits leaf breakdown in streams: A microcosm study with artificial reconstituted fresh water. Ecotoxicol. Environ. Safe. 2020, 196, 110535. [CrossRef] [PubMed]

15. Liang, C.; Zhang, B. Effect of exogenous calcium on growth, nutrients uptake and plasma membrane $\mathrm{H}^{+}$-ATPase and Ca ${ }^{2+}-\mathrm{ATPase}$ activities in soybean (Glycine max) seedlings under simulated acid rain stress. Ecotoxicol. Environ. Safe. 2018, 165, 261-269. [CrossRef]

16. Hüve, K.; Bichele, I.; Rasulov, B.; Niinemets, Ü. When it is too hot for photosynthesis: Heat-induced instability of photosynthesis in relation to respiratory burst, cell permeability changes and $\mathrm{H}_{2} \mathrm{O}_{2}$ formation. Plant Cell Environ. 2011, 34, 113-126. [CrossRef] [PubMed]

17. Kumar, N.; Shankhdhar, S.C.; Shankhdhar, D. Impact of elevated temperature on antioxidant activity and membrane stability in different genotypes of rice (Oryza sativa L.). Indian J. Plant Physiol. 2016, 21, 37-43. [CrossRef]

18. Wang, P.; Hu, T.; Kong, F.; Zhang, D. Changes in the spatial pattern of rice exposure to heat stress in China over recent decades. Clim. Change 2019, 154, 229-240. [CrossRef]

19. Fernández, L.C.D.; Luque, E.G.; Mercado, F.G.; Pedrosa, W. Influence of temperature and salinity on the germination of Limonium tabernense Erben from Tabernas Desert (Almería, SE Spain). Flora 2016, 218, 68-74. [CrossRef]

20. Wu, C.; Cui, K.; Tang, S.; Li, G.; Huang, J.; Peng, S.; Ding, Y. Intensified pollination and fertilization ameliorate heat injury in rice (Oryza sativa L.) during the flowering stage. Field Crop. Res. 2020, 252, 107795. [CrossRef]

21. Wang, Y.; Zhang, Y.; Shi, Q.; Chen, H.; Xiang, J.; Hu, G.; Chen, Y.; Wang, X.; Wang, J.; Yi, Z.; et al. Decrement of sugar consumption in rice young panicle under high temperature aggravates spikelet number reduction. Rice Sci. 2020, 27, 44-55. [CrossRef]

22. Wang, L.; Wang, W.; Zhou, Q.; Huang, X. Combined effects of lanthanum(III) chloride and acid rain on photosynthetic parameters in rice. Chemosphere 2014, 112, 355-361. [CrossRef]

23. Zafar, S.A.; Hameed, A.; Ashraf, M.; Khan, A.S.; Qamar, Z.; Li, X.; Siddique, K.H.M. Agronomic, physiological and molecular characterisation of rice mutants revealed the key role of reactive oxygen species and catalase in high-temperature stress tolerance. Func. Plant Biol. 2020, 47, 440-453. [CrossRef]

24. Mathur, S.; Agrawal, D.; Jajoo, A. Photosynthesis: Response to high temperature stress. J. Photochem. Photobiol. 2014, 137, 116-126. [CrossRef]

25. Yang, D.; Peng, S.; Wang, F. Response of photosynthesis to high growth temperature was not related to leaf anatomy plasticity in rice (Oryza sativa L.). Front. Plant Sci. 2020, 11, 26. [CrossRef]

26. Lee, D.; Nishizawa, M.; Shimizu, Y.; Saeki, H. Anti-inflammatory effects of dulse (Palmaria palmata) resulting from the simultaneous water-extraction of phycobiliproteins and chlorophyll a. Food Res. Int. 2017, 100, 514-521. [CrossRef]

27. Zhang, Y.; Yin, H.; Zhao, X.; Wang, W.; Du, Y.; He, A.; Sun, K. The promoting effects of alginate oligosaccharides on root development in Oryza sativa L. mediated by auxin signaling. Carbohydr. Polym. 2014, 113, 446-454. [CrossRef]

28. Ates, B.; Koytepe, S.; Ulu, A.; Gurses, C.; Thakur, V.K. Chemistry, structures, and advanced applications of nanocomposites from biorenewable resources. Chem. Rev. 2020, 120, 9304-9362. [CrossRef] [PubMed]

29. Zhang, Y.; Liu, H.; Yin, H.; Wang, W.; Zhao, X.; Du, Y. Nitric oxide mediates alginate oligosaccharides-induced root development in wheat (Triticum aestivum L.). Plant Physiol. Biochem. 2013, 71, 49-56. [CrossRef] [PubMed]

30. Xu, M.; Zhu, L.; Shou, H.; Wu, P. A PIN1 family gene, OsPIN1, involved inauxin-dependent adventitious root emergence and tillering in rice. Plant Cell Physiol. 2005, 46, 1674-1681. [CrossRef]

31. Ma, L.J.; Zhang, Y.; Bu, N.; Wang, S.H. Alleviation effect of alginate-derived oligosaccharides on Vicia faba root tip cells damaged by cadmium. Bull. Environ. Contam. Toxicol. 2010, 84, 161-164. [CrossRef] [PubMed]

32. Zhang, Y.H.; Yin, H.; Liu, H.; Wang, W.X.; Wu, L.S.; Zhao, X.M.; Du, Y.G. Alginate oligosaccharides regulate nitrogen metabolism via calcium in Brassica campestris L. var. utilis Tsen et Lee. J. Horticult. Sci. Biotechnol. 2013, 88, 502-508. [CrossRef]

33. Sarfaraz, A.; Naeem, M.; Nasir, S.; Idrees, M.; Aftab, T.; Hashmi, N.; Khan, M.M.A.; Moinuddin; Varshney, L. An evaluation of the effects of irradiated sodium alginate on the growth, physiological activities and essential oil production of fennel (Foeniculum vulgare Mill.). J. Med. Plants Res. 2011, 5, 15-21. [CrossRef]

34. Albersheim, P.; Darvill, A.G. Oligosaccharins: Novel molecules that can regulate growth, development, reproduction, and defense against disease in plants. Sci. Am. 1985, 253, 58-64. [CrossRef]

35. Liu, H.; Zhang, Y.-H.; Yin, H.; Wang, W.-X.; Zhao, X.-M.; Du, Y.-G. Alginate oligosaccharides enhanced Triticum aestivum L. tolerance to drought stress. Plant Physiol. Biochem. 2013, 62, 33-40. [CrossRef] [PubMed]

36. Zhang, C.; Howlader, P.; Liu, T.; Sun, X.; Jia, X.C.; Zhao, X.M.; Shen, P.L.; Qin, Y.M.; Wang, W.X.; Yin, H. Alginate oligosaccharide (AOS) induced resistance to Pst DC3000 via salicylic acid-mediated signaling pathway in Arabidopsis thaliana. Carbohydr. Polym. 2019, 225, 115221. [CrossRef]

37. He, J.; Li, R.; Sun, X.; Wang, W.; Hu, J.; Xie, H.; Yin, H. Effects of calcium alginate submicroparticles on seed germination and seedling growth of wheat (Triticum aestivum L.). Polymers 2018, 10, 1154. [CrossRef] 
38. Salachna, P.; Grzeszczuk, M.; Meller, E.; Mizielińska, M. Effects of gellan oligosaccharide and NaCl stress on growth, photosynthetic pigments, mineral composition, antioxidant capacity and antimicrobial activity in red perilla. Molecules 2019, $24,3925$. [CrossRef]

39. Tang, J.; Zhou, Q.; Chu, H.; Nagata, S. Characterization of alginase and elicitor-active oligosaccharides from Gracilibacillus A7 in alleviating salt stress for Brassica campestris L. J. Agric. Food Chem. 2011, 59, 7896-7901. [CrossRef]

40. Lemonnier-Le Penhuizic, C.; Chatelet, C.; Kloareg, B.; Potin, P. Carrageenan oligosaccharides enhance stress-induced microspore embryogenesis in Brassica oleracea var. italica. Plant Sci. 2001, 160, 1211-1220. [CrossRef]

41. Shabbir, A.; Khan, M.M.A.; Sadiq, Y.; Jaleel, H.; Ahmad, B.; Uddin, M. Regulation of functional activities and essential oil production in Vetiveria zizanioides L. Nash after $\gamma$-irradiated sodium alginate elicitation. Turk. J. Biol. 2017, 41, 661-672. [CrossRef]

42. Zhu, Y.; Di, T.; Xu, G.; Chen, X.; Zeng, H.; Yan, F.; Shen, Q. Adaptation of plasma membrane $\mathrm{H}^{+}$-ATPase of rice roots to low pH as related to ammonium nutrition. Plant Cell Environ. 2009, 32, 1428-1440. [CrossRef]

43. Dai, Z.; Liu, X.; Wu, J.; Xu, J. Impacts of simulated acid rain on recalcitrance of two different soils. Environ. Sci. Pollut. Res. 2013, 20, 4216-4224. [CrossRef] [PubMed]

44. Qin, P.; Du, Y.; Liu, J.; Song, L.; Liu, A.; Wang, Q. Distribution characteristics and influencing factors of acid rain in Guangdong Province. J. Tropic. Meteorol. 2006, 22, 297-300, (In Chinese with English abstract). [CrossRef]

45. Huang, J.; Wang, H.; Zhong, Y.; Huang, J.; Fu, X.; Wang, L.; Teng, W. Growth and physiological response of an endangered tree, Horsfieldia hainanensis Merr., to simulated sulfuric and nitric acid rain in southern China. Plant Physiol. Biochem. 2019, 144, 118-126. [CrossRef]

46. Wang, J.; Zeng, Q.; Zhu, J.; Liu, G.; Tang, H. Dissimilrity of ascorbate-glutathione (AsA-GSH) cycle mechanism in two rice (Oryza sativa L.) cultivars under experimental free-air ozone exposure. Agric. Ecosyst. Environ. 2013, 165, 39-49. [CrossRef]

47. Shah, K.; Kumar, R.G.; Verma, S.; Dubey, R.S. Effect of cadmium on lipid peroxidation, superoxide anion generation and activities of antioxidant enzymes in growing rice seedlings. Plant Sci. 2001, 161, 1135-1144. [CrossRef]

48. Gassama, U.M.; Puteh, A.B.; Abd-Halim, M.R.; Kargbo, B. Influence of municipal wasterwater on rice seed germination, seedling performance, nutrient uptake, and chlorophyll content. J. Crop Sci. Biotechnol. 2015, 18, 9-19. [CrossRef]

49. Fidalgo, F.; Azenha, M.; Silva, A.F.; de Sousa, A.; Santiago, A.; Ferraz, P.; Teixeira, J. Copper-induced stress in Solanum nigrum L. and antioxidant defense system responses. Food Energy Secur. 2013, 2, 70-80. [CrossRef]

50. Soares, C.; de Sousa, A.; Pinto, A.; Azenh, M.; Teixeira, J.; Azevedo, R.A.; Fidalgo, F. Effect of 24-epibrassinolide on ROS content, antioxidant system, lipid peroxidation and Ni uptake in Solanum nigrum L. under Ni stress. Environ. Exp. Bot. 2016, 122, 115-125. [CrossRef]

51. Bradford, M.M. A rapid and sensitive method for the quantification of microgram quantities of protein utilizing the principle of protein-dye binding. Anal. Biochem. 1976, 72, e254. [CrossRef]

52. Liu, Y.-F.; Zhang, G.-X.; Qi, M.-F.; Li, T.-L. Effects of calcium on photosynthesis, antioxidant system and chloroplast ultrastructure in tomato leaves under low night temperature stress. J. Plant Growth Regul. 2015, 34, 263-273. [CrossRef]

53. Gabara, B.; Skłodowska, M.; Wyrwicka, A.; Glińska, S.; Gapińska, M. Changes in the ultrastructure of chloroplasts and mitochondria and antioxidant enzyme activity in Lycopersicon esculentum Mill. leaves sprayed with acid rain. Plant Sci. 2003, 164, 507-516. [CrossRef]

54. Chen, F.; Wang, F.; Wu, F.; Mao, W.; Zhang, G.; Zhou, M. Modulation of exogenous glutathione in antioxidation defense system against Cd stress in the two barley genotypes differing in Cd tolerance. Plant Physiol. Biochem. 2010, 48, 663-672. [CrossRef]

55. Ara, N. Dissecting the heat stress-induced alterations in the leaf ultrastructure and some antioxidant network components in interspecific (Cucurbita maxima $\times$ Cucurbita moschata) inbred line of squash 'Maxchata' as to its parents possessing variable heat tolerance. Plant Growth Regul. 2015, 76, 289-301. [CrossRef]

56. Gilani, M.M.; Tigabu, M.; Liu, B.; Farooq, T.H.; Rashid, M.H.U.; Ramzan, M.; Ma, X.Q. Seed germination and seedling emergence of four tree species of southern China in response to acid rain. J. For. Res. 2021, 32, 471-481. [CrossRef]

57. Rodrigues, A.A.; Vasconcelos, S.C.; Muller, C.; Rodrigues, D.A.; Mendes, G.C.; Rehn, L.S.; Costa, A.C.; Vital, R.G.; Sales, J.D. Sapindus saponaria bioindicator potential concerning potassium fluoride exposure by simulated rainfall: Anatomical and physiological traits. Ecol. Indic. 2018, 89, 552-558. [CrossRef]

58. Vani, B.; Saradhi, P.P.; Mohanty, P. Alteration in chloroplast structure and thylakoid membrane composition due to in vivo heat treatment of rice seedlings: Correlation with the functional changes. J. Plant Physiol. 2001, 158, 583-592. [CrossRef]

59. Satoh, K.; Saji, S.; Ito, S.; Shimizu, H.; Saji, H.; Kikuchi, S. Gene response in rice plants treated with continuous fog influenced by $\mathrm{pH}$, was similar to that treated with biotic stress. Rice 2014, 7, 10. [CrossRef]

60. Li, T.; Wang, X.; Zhou, Q.; Liao, C.; Zhou, L.; Wan, L.; An, J.; Du, Q.; Li, N.; Ren, Z.J. Swift acid rain sensing by synergistic rhizospheric bioelectrochemical responses. ACS Sensor 2018, 3, 1424-1430. [CrossRef]

61. Ju, S.; Wang, L.; Zhang, C.; Yin, T.; Shao, S. Alleviatory effects of silicon on the foliar micromorphology and anatomy of rice (Oryza sativa L.) seedlings under simulated acid rain. PLoS ONE 2017, 12, 124-135. [CrossRef]

62. Jumrani, K.; Bhatia, V.S.; Pandey, G.P. Impact of elevated temperatures on specific leaf weight, stomatal density, photosynthesis and chlorophyll fluorescence in soybean. Photosynth. Res. 2017, 131, 333-350. [CrossRef]

63. Zhang, Y.; Yin, H.; Wang, W.; Zhao, X.; Du, Y.; Wu, L. Enhancement in photosynthesis characteristics and phytohormones of flowering Chinese cabbage (Brassica campestris L. var. utilis Tsen et Lee) by exogenous alginate oligosaccharides. J. Food Agric. Environ. 2013, 11, 669-675. [CrossRef] 
64. Guo, W.; Yin, H.; Ye, Z.; Zhao, X.; Yuan, J.; Du, Y. A comparison study on the interactions of two oligosaccharides with tobacco cells by time-resolved fluorometric method. Carbohydr. Polym. 2012, 90, 491-495. [CrossRef] [PubMed]

65. Liu, R.; Jiang, X.; Guan, H.; Li, X.; Du, Y.; Wang, P.; Mou, H. Promotive effects of alginate-derived oligosaccharides on the inducing drought resistance of tomato. J. Ocean Univ. Chin. 2009, 8, 303-311. [CrossRef]

66. Da Fonseca, S.S.; da Silva, B.R.S.; Lobato, A.K.D. 24-Epibrassinolide positively modulate leaf structures, antioxidant system and photosynthetic machinery in rice under simulated acid rain. J. Plant Growth Regul. 2020, 39, 1559-1576. [CrossRef]

67. Ma, L.J.; Li, X.M.; Bu, N.; Li, N. An alginate-derived oligosaccharide enhanced wheat tolerance to cadmium stress. Plant Growth Regul. 2010, 62, 71-76. [CrossRef]

68. Zhang, S.; Tang, W.; Jiang, L.; Hou, Y.; Yang, F.; Chen, W.; Li, X. Elicitor activity of algino-oligosaccharide and its potential application in protection of rice plant (Oryza saliva L.) against Magnaporthe grisea. Biotechnol. Biotechn. Equip. 2015, 29, 646-652. [CrossRef]

69. Tusi, K.S.; Khalaj, L.; Ashabi, G.; Kiaei, M.; Khodagholi, F. Alginate oligosaccharide protects against endoplasmic reticulum- and mitochondrial-mediated apoptotic cell death and oxidative stress. Biomaterials 2011, 32, 5438-5458. [CrossRef]

70. González, A.; Castro, J.; Vera, J.; Moenne, A. Seaweed oligosaccharides stimulate plant growth by enhancing carbon and nitrogen assimilation, basal metabolism, and cell division. J. Plant Growth Regul. 2013, 32, 443-448. [CrossRef]

71. Peng, Q.; Zhang, M.; Gao, L.; Eromosele, O.; Qiao, Y.; Shi, B. Effects of alginate oligosaccharides with different molecular weights and guluronic to mannuronic acid ratios on glyceollin induction and accumulation in soybeans. J. Food Sci. Technol. 2018, 55, 1850-1858. [CrossRef] 